\title{
A NATUREZA LÓGICA E SEMIÓTICA DOS SIGNOS DE PRIMEIRIDADE THE LOGICAL AND SEMIOTIC NATURE OF THE 'PRIMEIRIDADE' SIGNS
}

\author{
Doutorando André Luiz Ming Garcia ${ }^{1}$ \\ Universidade de São Paulo- USP \\ andrelunar@gmail.com \\ Prof. Dr. Helmut Galle \\ (Orientador)
}

\begin{abstract}
Resumo: Em diversas ocasiões, Charles |Sanders Peirce afirmou que os únicos tipos de signos realmente genuínos seriam os de terceiridade (símbolo, legi-signo e argumento), uma vez que consistem em signos que representam algo distinto deles mesmos, e também porque todos os elementos que os compõem (representamen, objeto e interpretante) podem ser de natureza sígnica. Em sua correspondência com Lady Welby, entretanto, Peirce afirmou ter rebaixado o grau de abstração de suas reflexões com vistas a tornálas mais palatáveis e compreensíveis. Tendo em vista a afirmação peirceana de que tudo, inclusive o homem, é signo, argumenta-se neste argumento que signos de primeiridade (ícones, quali-signos e remas) não são apenas quase-signos, mas signos com propriedades e estofo ontológico e lógico complexo e de extrema validez para a análise da arte, sobretudo aquela ensimesmada, autorreferencial e abstrata, que discursa sobre si mesma e suas qualidades. Como exemplos, serão utilizadas obras de arte visual e o livro ilustrado para ilustrar a argumentação.
\end{abstract}

Palavras-chave: Semiótica; signos; primeiridade; Charles Sanders Peirce

Abstract: On several occasions, Sanders Peirce stated that the only truly genuine types of signs would be those of thirdness (symbol, legi-sign and argument), since they consist of signs that represent something distinct from themselves, and also because all the elements that compose them (representamen, object and interpretant) can be of a symbolic nature. In his correspondence with Lady Welby, however, Peirce claimed to have lowered the degree of abstraction of his reflections in order to make them more palatable and comprehensible. In view of Peirce's assertion that everything, including man, is a sign, it is argued in this argument that signs of firstness (icons, quali-signs and remas) are not only quasi-signs, but signs with ontological and logical complexity and are extremely valid for the analysis of art, especially that of selfreferential, and abstract nature, which speaks about itself and its qualities. As examples, works of visual art and the illustrated book will be used to illustrate the argumentation.

Keywords: Semiotics; Signs; Firstness; Charles Sanders Peirce

\section{Introdução}

Em Peirce, entendemos que a terceiridade é, por excelência, a categoria dos signos e da semiose. Por esse motivo, signos de primeiridade e de secundidade são por ele, eventualmente, denominados quase-signos. Para muitos autores, a semiótica deverse-ia dedicar especial ou exclusivamente a signos de terceiridade, nos quais os três correlatos são de ordem sígnica e a semiose se apresenta em sua forma mais complexa e genuína, nos níveis da representação e da comunicação, mas Santaella (1992, p. 46) nos diz que ela consiste em uma "doutrina formal de todos os tipos possíveis de semiose".

Signos de primeiridade, tanto aqueles que são "meras" possibilidades quanto os que são "meras" qualidades ou "meros" sentimentos, são fundamentais no estudo da arte, uma área que tradicionalmente é investigada tendo a(s) semiótica(s) como fundamentação, embora, como nos mostra Santaella (1992, p. 43), não se deva

\footnotetext{
${ }^{1}$ Doutorando em Letras pela Universidade de São Paulo. A pesquisa aqui apresentada foi concluída sob a orientação do Prof. Dr. Helmut Galle.
} 
confundir a semiótica enquanto ciência e teoria "com as áreas potenciais a que pode ser aplicada". Assim, a semiótica fundamenta o estudo da arte, mas não se confunde com ela e nem invalida ou substitui as diversas teorias da arte - ao contrário, a elas deve aliar-se.

Um dos principais objetivos deste trabalho é reafirmar o lugar central e privilegiado da primeiridade e dos signos a ela relacionados no estudo da arte e de sua fruição, bem como sublinhar a questão da alo-referencialidade na arte e seu lugar na semiótica. Mas, para falar de signos de primeiridade, teremos de retomar as definições de signo que Peirce nos ofereceu. Observando 39 definições de signo elaboradas por Peirce (tabela na sequência) ao longo de seus escritos num período que vai de 1868 a 1910, encontram-se ao menos onze nas quais Peirce afirma categórica e claramente que o signo substitui um objeto que é diferente dele mesmo, ou seja, que o objeto é ou deva ser distinto do representamen ${ }^{2}$. Essas partes estão em negrito nas citações, e os negritos são todos interferências minhas. Os itálicos, por sua vez, são parte dos originais de Peirce.

Veja-se que, em 1902 (MS [R] 599:38), Peirce afirmou que "um signo que meramente representa a si mesmo para si mesmo não é nada além daquela coisa em si mesma”. Então, com base nesse raciocínio, haveria coisas em si que não consistiriam em signos. Mas não teria afirmado Peirce, em outros momentos, que absolutamente tudo é signo, inclusive o próprio homem? Estamos, portanto, diante de um excitante impasse. Há ou não há fenômenos ou coisas que não são signos? Procuraremos responder a estas perguntas no presente texto.

\section{As definições peirceanas de signo e a discussão sobre signos, não-signos e quase- signos}

Observemos, na seguinte tabela, as definições de signo ao longo da obra de Peirce, segundo a compilação de Bergman \& Paavola (2016).

\footnotetext{
${ }^{2}$ Como exemplo de ocorrência em que signo e objeto são a mesma coisa, Peirce cita um mapa colocado em cima da superfície que ele mapeia (MS [R] 9:1, 1903): "Um signo pretende corresponder a uma coisa real, ou a algo relativamente real; e este objeto do signo pode ser o próprio signo, como quando um mapa é precisamente superposto àquilo que ele mapeia".
} 


\begin{tabular}{|c|c|c|}
\hline \multicolumn{3}{|r|}{ Verbete: signo (sign) } \\
\hline Ano & Referência & Trecho selecionado \\
\hline 1868 & W 2:223 & $\begin{array}{l}\text {... a sign has, as such, three references: } 1 \text { st, it is a sign to some } \\
\text { thought which interprets it; } 2 \mathrm{~d} \text {, it is a sign for some object to } \\
\text { which in that thought it is equivalent; } 3 \mathrm{~d} \text {, it is a sign, in some } \\
\text { respect or quality, which brings it into connection with its object. }\end{array}$ \\
\hline 1873 & W 3:66-8 & A sign is an object which stands for another to some mind \\
\hline 1873 & CP 7.355-6 & $\begin{array}{l}\text {... a thing which stands for another thing is a representation or } \\
\text { sign. }\end{array}$ \\
\hline 1885 & W 5:162 & $\begin{array}{l}\text { A sign is in a conjoint relation to the thing denoted and to the } \\
\text { mind. }\end{array}$ \\
\hline $1893-5$ & CP 1.339 & $\begin{array}{l}\text { A sign stands for something to the idea which it produces, or } \\
\text { modifies }\end{array}$ \\
\hline 1895 & EP 2:13 & $\begin{array}{l}\text { A sign is a thing which serves to convey knowledge of some } \\
\text { other thing, which it is said to stand for or represent. }\end{array}$ \\
\hline 1897 & CP 2.228 & $\begin{array}{l}\text { A sign, or representamen, is something which stands to } \\
\text { somebody for something in some respect or capacity [...]The sign } \\
\text { stands for something, its object. It stands for that object, not in all } \\
\text { respects, but in reference to a sort of idea, which I have } \\
\text { sometimes called the ground of the representamen. }\end{array}$ \\
\hline 1902 & NEM 4:54 & $\begin{array}{l}\text { A sign is something, } A \text {, which brings something, } B \text {, its } \\
\text { interpretant sign, determined or created by it, into the same sort } \\
\text { of correspondence (or a lower implied sort) with something, } C \text {, } \\
\text { its object, as that in which itself stands to } C\end{array}$ \\
\hline 1902 & $\begin{array}{l}\text { NEM 4:20- } \\
1\end{array}$ & $\begin{array}{l}\text {... a sign is something, } A \text {, which brings something, } B \text {, its } \\
\text { interpretant sign determined or created by it, into the same sort of } \\
\text { correspondence with something, } C \text {, its object, as that in which } \\
\text { itself stands to } C \text {. }\end{array}$ \\
\hline 1902 & $\begin{array}{l}\text { MS [R] } \\
599: 28-36\end{array}$ & $\begin{array}{l}\text { What is a sign? It is anything which in any way represents an } \\
\text { object. This statement leaves us the difficulty of saying what } \\
\text { "representing" is. Yet it affords help by pointing out that every } \\
\text { sign refers to an object. }\end{array}$ \\
\hline 1902 & $\begin{array}{l}\text { MS [R] } \\
599: 38\end{array}$ & $\begin{array}{l}\text { A sign is something which in some measure and in some respect } \\
\text { makes its interpretant the sign of that of which it is itself the sign. } \\
{[-][\mathrm{A}] \text { sign which merely represents itself to itself is nothing }} \\
\text { else but that thing itself. }\end{array}$ \\
\hline 1903 & $\begin{array}{l}\text { MS [R] } \\
462: 74\end{array}$ & $\begin{array}{l}\text {... a sign is a thing related to an object and determining in the } \\
\text { interpreter an interpreting sign of the same object. It involves the } \\
\text { relation between sign, interpreting sign, and object. }\end{array}$ \\
\hline 1903 & CP 1.346 & $\begin{array}{l}\text {... a sign is something, A, which denotes some fact or object, } \boldsymbol{B} \text {, to } \\
\text { some interpretant thought, C }\end{array}$ \\
\hline
\end{tabular}




\begin{tabular}{|c|c|c|}
\hline 1904 & CP 8.191 & $\begin{array}{l}\text { "Representation" and "sign" are synonyms. The whole purpose of } \\
\text { a sign is that it shall be interpreted in another sign; and its whole } \\
\text { purport lies in the special character which it imparts to that } \\
\text { interpretation. When a sign determines an interpretation of itself } \\
\text { in another sign, it produces an effect external to itself, a physical } \\
\text { effect, though the sign producing the effect may itself be not an } \\
\text { existent object but merely a type. It produces this effect, not in } \\
\text { this or that metaphysical sense, but in an indisputable sense. }\end{array}$ \\
\hline 1904 & CP 8.332 & $\begin{array}{l}\text { A sign mediates between the interpretant sign and its object. } \\
\text { Taking sign in its broadest sense, its interpretant is not necessarily } \\
\text { a sign. }[-] \text { A sign }[\ldots] \text { is an object which is in relation to its } \\
\text { object on the one hand and to an interpretant on the other in such } \\
\text { a way as to bring the interpretant into a relation to the object } \\
\text { corresponding to its own relation to the object }\end{array}$ \\
\hline 1905 & $\begin{array}{l}\text { MS [R] } \\
939: 42-4\end{array}$ & $\begin{array}{l}\text { It is difficult to define a sign in general. It is something which is } \\
\text { in such a relation to an object that it determines, or might } \\
\text { determine, another sign of the same object. This is true but } \\
\text { considered as a definition it would involve a vicious circle, since } \\
\text { it does not say what is meant by the interpretant being a "sign" of } \\
\text { the same object. However, this much is clear; that a sign has } \\
\text { essentially two correlates, its Object and its possible Interpretant } \\
\text { sign. Of these three, Sign, Object, Interpretant, the Sign as being } \\
\text { the very thing under consideration is Monadic, the Object is } \\
\text { Dyadic, and the Interpretant is Triadic. We therefore look to see, } \\
\text { whether there be not two Objects and three Interpretants. There } \\
\text { obviously are two Objects, the object as it is in itself (the } \\
\text { Monadic Object), and the object as the sign represents it to be (the } \\
\text { Dyadic Object). There are also three Interpretants; namely, 1st, } \\
\text { the Interpretant considered as an independent sign of the Object, } \\
\text { 2nd, the Interpretant as it is as a fact determined by the Sign to be, } \\
\text { and 3rd the Interpretant as it is intended by, or is represented in, } \\
\text { the Sign to be. }\end{array}$ \\
\hline $\begin{array}{l}1905- \\
07\end{array}$ & EP 2:390-1 & $\begin{array}{l}\text { A medium of communication is something, } A \text {, which being acted } \\
\text { upon by something else, } N \text {, in its turn acts upon something, } I \text {, in a } \\
\text { manner involving its determination by } N \text {, so that I shall thereby, } \\
\text { through } A \text { and only through } A \text {, be acted upon by } N \text {. }\end{array}$ \\
\hline 1906 & $\begin{array}{l}\text { MS [R] } \\
283: 109-10\end{array}$ & $\begin{array}{l}\text { We can say, at once, that a sign must have these three characters: } \\
\text { First, it must be a recognizable object in itself. Secondly, it must } \\
\text { be determined to correspond, according to some principle, and by } \\
\text { some species of causation, with something else, called its } \text { Object. }\end{array}$ \\
\hline 1906 & EP 2:544 & $\begin{array}{l}\text { As a medium, the Sign is essentially in a triadic relation, to its } \\
\text { Object which determines it, and to its Interpretant which it } \\
\text { determines. In its relation to the Object, the Sign is passive; that is } \\
\text { to say, its correspondence to the Object is brought about by an } \\
\text { effect upon the Sign, the Object remaining unaffected. On the } \\
\text { other hand, in its relation to the Interpretant the Sign is active, } \\
\text { determining the Interpretant without being itself thereby affected. }\end{array}$ \\
\hline 1906 & $\begin{array}{l}\text { MS [R] } \\
339: 271 \mathrm{r}\end{array}$ & $\begin{array}{l}\text { The object, } \boldsymbol{O} \text {, determines the sign, } \mathrm{S} \text {, and } \mathrm{S} \text { determines the } \\
\text { Interpreting sign, I, to being determined by } \mathrm{O} \text { through } \mathrm{S} \text {. }\end{array}$ \\
\hline
\end{tabular}




\begin{tabular}{|c|c|c|}
\hline 1907 & $\begin{array}{l}\text { MS [R] } \\
318: 13-4\end{array}$ & $\begin{array}{l}\text {...any sign, of whatsoever kind, professes to mediate between an } \\
\text { Object, on the one hand, that to which it applies, and which is } \\
\text { thus in a sense the cause of the sign, and, on the other hand, a } \\
\text { Meaning, or to use a preferable technical term, an Interpretant, } \\
\text { that which the sign expresses, the result which it produces in its } \\
\text { capacity as sign. }\end{array}$ \\
\hline 1907 & $\begin{array}{l}\text { MS [R] } \\
318: 11-2\end{array}$ & $\begin{array}{l}\text {...any sign, of whatever kind, mediates between an object to } \\
\text { some sort of conformity with which it is moulded, and which thus } \\
\text { determines it, and an effect which it is intended to produce, and } \\
\text { which it represents to be the outcome of the object. }\end{array}$ \\
\hline 1907 & $\begin{array}{l}\text { MS [R] } \\
318: 19\end{array}$ & $\begin{array}{l}\text { A "sign,", I say, shall be understood as anything which represents } \\
\text { itself to convey an influence from an Object, so that this may } \\
\text { intelligently determine a "meaning," or interpretant. }\end{array}$ \\
\hline 1907 & EP 2:410 & $\begin{array}{l}\text { I will say that a sign is anything, of whatsoever mode of being, } \\
\text { which mediates between an object and an interpretant; since it is } \\
\text { both determined by the object relatively to the interpretant, and } \\
\text { determines the interpretant in reference to the object, in such wise } \\
\text { as to cause the interpretant to be determined by the object through } \\
\text { the mediation of this "sign." }\end{array}$ \\
\hline 1907 & $\begin{array}{l}\text { MS [R] } \\
318: 14-5\end{array}$ & $\begin{array}{l}\text {...the essential nature of a sign is that it mediates between its } \\
\text { Object which is supposed to determine it and to be, in some } \\
\text { sense, the cause of it, and its Meaning, or, as I prefer to say, in } \\
\text { order to avoid certain ambiguities, its Interpretant, which is } \\
\text { determined by the sign; and is, in a sense, the effect of it; and } \\
\text { which the sign represents to flow as an influence, from the } \\
\text { Object. [- - So far, so good: the Object, the determinant of the } \\
\text { Sign, and the Meaning, or Interpretant, that which the sign, as } \\
\text { such, determines, its effect. }\end{array}$ \\
\hline 1907 & $\begin{array}{l}\text { MS [R] } \\
318: 18-9\end{array}$ & $\begin{array}{l}\text { A sign is whatever there may be whose intent is to mediate } \\
\text { between an utterer of it and an interpreter of it, both being } \\
\text { repositories of thought, or quasi-minds, by conveying a meaning } \\
\text { from the former to the latter. We may say that the sign is moulded } \\
\text { to the meaning in the quasi-mind that utters it, where it was, } \\
\text { virtually at least, (i.e. if not in fact, yet the moulding of the sign } \\
\text { took place as if it had been there,) already an ingredient of } \\
\text { thought. }\end{array}$ \\
\hline 1907 & $\begin{array}{l}\text { MS [R] } \\
318: 38\end{array}$ & $\begin{array}{l}\text { I will suggest that a sign is anything which being intelligently } \\
\text { determined by an Object in its turn intelligently determines an } \\
\text { Interpretant, which thus becomes mediately determined by the } \\
\text { Object. }\end{array}$ \\
\hline 1907 & $\begin{array}{l}\text { MS [R] } \\
321: 15-6, \\
19\end{array}$ & $\begin{array}{l}\text {... any sign, of whatsoever kind, mediates between an Object to } \\
\text { some sort of conformity with which it is moulded, and by which it } \\
\text { is thus determined, and an effect which the sign is intended to } \\
\text { bring about, and which it represents to be the outcome of the } \\
\text { object's influence upon it }\end{array}$ \\
\hline 1908 & SS 80-81 & $\begin{array}{l}\text { I define a Sign as anything which is so determined by something } \\
\text { else, called its Object, and so determines an effect upon a person, } \\
\text { which effect I call its Interpretant, that the latter is thereby } \\
\text { mediately determined by the former }\end{array}$ \\
\hline
\end{tabular}




\begin{tabular}{|c|c|c|}
\hline 1908 & CP 8.343 & $\begin{array}{l}\text { I define a Sign as anything which on the one hand is so } \\
\text { determined by an Object and on the other hand so determines an } \\
\text { idea in a person's mind, that this latter determination, which I } \\
\text { term the Interpretant of the sign, is thereby mediately determined } \\
\text { by that Object. A sign, therefore, has a triadic relation to its } \\
\text { Object and to its Interpretant. }\end{array}$ \\
\hline 1909 & EP 2:492 & $\begin{array}{l}\text { A Sign is a Cognizable that, on the one hand, is so determined } \\
\text { (i.e., specialized, bestimmt) by something other than itself, called } \\
\text { its Object }\end{array}$ \\
\hline 1909 & $\begin{array}{l}\text { MS [R] } \\
637: 31-32\end{array}$ & $\begin{array}{l}\text { But in order that anything should be a Sign, it must "represent," } \\
\text { as we say, something else, called its Object, although the } \\
\text { condition that a Sign must be other than its Object is perhaps } \\
\text { arbitrary, since, if we insist upon it we must make an exception in } \\
\text { the case of a Sign that is a part of a Sign. }\end{array}$ \\
\hline 1909 & $\begin{array}{l}\text { MS [R] } \\
637: 36\end{array}$ & $\begin{array}{l}\text { It is not only essential to a Sign that it should represent, i.e. stand } \\
\text { in place of or for, an Object, but, if possible, still more so that it } \\
\text { should be capable of Interpretation by or through a mind, into } \\
\text { which it implants a germ which, on development, will affect the } \\
\text { conduct of the person to whom that mind appertains }\end{array}$ \\
\hline 1909 & $\begin{array}{l}\text { MS [R] } \\
640: 7-8 \\
\end{array}$ & $\begin{array}{l}\text { A Sign }[\ldots] \text { is anything which represents something else, its } \\
\text { Object, to any mind that can Interpret it so }\end{array}$ \\
\hline 1909 & MS [R] 277 & $\begin{array}{l}\text { A Sign is anything which represents something else (so far as it } \\
\text { is complete), and if it represents itself it is as a part of another } \\
\text { sign which represents something other than itself, and it } \\
\text { represents itself in other circumstances, in other connections. }\end{array}$ \\
\hline 1910 & $\begin{array}{l}\text { MS [R] } \\
654: 7\end{array}$ & $\begin{array}{l}\text { By a sign I mean anything whatever, real or fictile, which is } \\
\text { capable of a sensible form, is applicable to something other than } \\
\text { itself, that is already known, and that is capable of being so } \\
\text { interpreted in another sign which I call its Interpretant as to } \\
\text { communicate something that may not have been previously } \\
\text { known about its Object. There is thus a triadic relation between } \\
\text { any Sign, an Object, and an Interpretant. }\end{array}$ \\
\hline 1910 & $\begin{array}{l}\text { MS [R] } \\
678: 23\end{array}$ & $\begin{array}{l}\text {...we apply this word "sign" to everything recognizable whether } \\
\text { to our outward senses or to our inward feeling and imagination, } \\
\text { provided only it calls up some feeling, effort, or thought... }\end{array}$ \\
\hline 1910 & ILS 284 & $\begin{array}{l}\text { A sign in general is } 1 \text { st something Real, that is } 2 \text { nd applicable to } \\
\text { an object different from itself and already known to the person } \\
\text { to whom it is a sign, and 3rd is capable of interpretation in the } \\
\text { mind of that person, so that it will (or would if accepted as } \\
\text { veracious sign) have some effect upon him of a kind it was } \\
\text { calculated or fit to have. }\end{array}$ \\
\hline $\mathrm{Nd}$ & $\begin{array}{l}\text { MS [R] } \\
914: 5-6\end{array}$ & $\begin{array}{l}\text { Every sign has an object, which may be regarded either as it is } \\
\text { immediately represented in the sign to be [or] as it is in it own } \\
\text { firstness. }\end{array}$ \\
\hline
\end{tabular}

Tabela 1: Definições de "signo" por Peirce recompiladas por Bergman e Paavola.

Magariños (2008) diz que há coisas que estão ou foram semiotizadas e outras que não, postulando a existência, de um lado, de signos (entes que semiotizam) e, de 
outro, de objetos semióticos (entes que são semiotizados, passíveis de semiotização). Os objetos semióticos, para este autor, não são signos até que os semiotizemos, que os (res)signifiquemos. Antes disso, ou seja, antes de serem incluídos e referidos em discursos e enunciações, não teriam identidade e "carece[ria]m de existência ontológica" (p. 22). O autor admite, porém que "o que em um momento é signo em outro passa a ser objeto semiótico e vice-versa" (idem, ibidem, itálico do original). Magariños acredita que é importante reconhecer a existência de entes que não são signos porque, "se tudo é signo, o signo não pode ser objeto de conhecimento científico, já que não tem outro objeto de conhecimento do qual diferenciar-se" (p. 21).

O problema do raciocínio de Magariños é que, em nenhum momento do seu texto, ele faz referência à possibilidade ou potencialidade e seu lugar na semiótica. Ele deixa de lado o fato de que um signo possa ser apenas uma possibilidade, e de que cada um de seus correlatos possa ser igualmente apenas uma possibilidade ou esse in futuro. Ele nos fala de signos e não-signos de forma extremamente objetiva, positivista. Mas a semiótica prevê que signos e seus correlatos possam ser simplesmente possíveis, e não necessariamente reais. Quanto à necessidade de que se postule a existência de nãosignos para diferenciar a semiótica daquilo que ela estuda, julgo importante considerar a teoria semiótica, assim como a linguística, como uma metassemiótica, ou seja, um sistema de signos tratando de (sistemas de) signos. Além disso, um signo está sempre caracterizado por uma aspectualização ou perspectivismo, sendo-lhe inerente a incompletude. Os signos utilizados para analisar signos são, na verdade, aspectos de signos usados para analisar aspectos de outros signos.

Silveira (2007) nos mostra que o objeto de um signo cujo representamen é mera possibilidade consiste também em mera possibilidade, e que os objetos podem ser algo a vir a ser criado pelo próprio signo, determinando-o a posteriori. Segundo Silveira, apenas no caso do símbolo o objeto deve ser algo distinto do signo, o que nos leva a entender que, no caso do ícone e do índice, signo e objeto podem coincidir. Assim, se a representação de um signo cujo objeto é distinto do representamen é classicamente um triângulo, a representação de um signo autorreferencial é um binômio, representável apenas por uma linha: 
Figura 1: Representação da estrutura de um signo em que representamen e objeto são o mesmo elemento.

O conceito de semiotização de Magariños, embora não sirva, ao meu ver, para distinguir signos de não-signos, uma vez que estou convencido de que tudo é signo, serve imensamente na análise do objeto artístico, uma vez que este pode ser significado e ressignificado indefinidamente, e, dadas a sua ambiguidade e polivalência intrínsecas, são criados para serem (res)significados de múltiplas e talvez infinitas formas.

Sobre a semiotização dos objetos referenciais do mundo, Nöth (2000) afirma que, de todas as formas, vivemos num mundo já semiotizado, e sugere que desistamos de tentar analisar uma suposta realidade paralela e alheia aos sistemas de signos. Até porque, como vimos, o contato com o objeto dinâmico sempre é mediado pelo objeto imediato, que é sempre de natureza indiscutivelmente sígnica. Nöth cita Eco, segundo quem a significação é puramente cultural. Sobre a existência de um mundo factual extrassemiótico, esta seria impossível de se confirmar, já que tudo o que existe chega a nós como signos, que são determinados culturalmente e têm a propriedade intrínseca de mentir. Pode-se adicionar, aqui, que lidamos na vida muito mais com precípua que com perceptos em si.

Sobre a distinção entre signos e coisas, Santaella (1992, p. 76-77) nos mostra que

O mundo não está dividido entre coisas, de um lado, e signos, de outro. Para Peirce "qualquer outra coisa que qualquer coisa possa ser, ela também é um signo" (Fisch 1983:56). Isto quer dizer: não há nada que não possa ser um signo, ou melhor, tudo é signo, ou melhor ainda, todas as coisas têm sua própria assinatura. [...] pensar algo como signo não significa ter de pensar que, sendo signo, ou, para ser signo, este algo não possa ser nada além de signo (Ransdell 1983:16). Ao contrário, todo signo pressupõe e envolve uma substancialidade ontológica e uma talidade qualitativa. Para funcionar como signo, algo tem de estar materializado numa existência singular, que tem um lugar no mundo (real ou fictício) e reage em relação a outros existentes de seu universo. Assim também, não há existente que não tenha um aspecto puramente qualitativo, sua talidade que o faz ser aquilo que é, tal como é. Essas três gradações, baseadas nas categorias de qualidade 
(primeiridade), reação (secundidade) e mediação (terceiridade), são onipresentes. Desse modo, nossa percepção delas depende, de um lado, do ponto de vista que assumimos no ato de recepção dos signos, de outro, depende também do aspecto que prepondera no signo: sua qualidade, sua existência concreta (ou seja, seu aspecto de "coisa") ou seu caráter de lei (ou seja, sua dimensão mais propriamente sígnica).

Segundo Romanini (2014, p. 374), a própria matéria é uma forma de mente:

O que chamamos de matéria é uma forma de mente tão enrijecida por hábitos - as leis da natureza - que praticamente deixou de produzir efeitos inesperados e passou a se comportar com uma regularidade acentuada, embora não absoluta. Para Peirce, a matéria mantém na sua estrutura mais fina e profunda algum grau de flutuação aleatória, de choque e aniquilação de elementos e de transformação que repetem, ainda que de forma esmaecida, os processos sintéticos típicos da atividade mental.

E, sobre a realidade, assevera:

Para Peirce, a realidade é, portanto, da natureza de um símbolo que cresce e se desenvolve animado por propósitos. Esses propósitos são virtuais, ou seja, são condicionais futuros que expressam um "vir a ser" ou "virtude" que, na filosofia grega de tradição platônica, era chamado de summum bonum, a união do belo, do bom e do verdadeiro (EP 2:377 e 388). (idem, ibidem, p. 373)

Um aspecto importante a ser considerado quando pensamos em coisas em si ou em coisas materiais, existentes no mundo real ou fenomênico consensual e independentes do que possamos pensar sobre elas, é que elas são perceptíveis (perceptos que se tornam percipua). Tudo o que existe como coisa é potencialmente perceptível, ainda que as percepções dependam dos sentidos de que esteja munida cada espécie de ser senciente. Assim, sabemos que gatos não vêm todas as cores que humanos vêm, ou ao menos não as vêm nos mesmos tons. Mas essas cores estão lá, assim como possivelmente estejam outras que os olhos humanos não são capazes de identificar. Certamente, o universo está repleto de existentes que exigiriam sentidos super-humanos para serem percebidos. Mas, potencialmente, tudo o que existe declara suas próprias características para um intérprete capacitado potencial.

Se tomarmos como exemplo as artes visuais, pode-se afirmar que o artista que as cria elabora um discurso de natureza visual. Esse discurso visual, antes de assumir características indiciais e simbólicas, é pura demonstração das qualidades da imagem. No caso da arte abstrata, as qualidades ostentadas pelo objeto podem ser tudo o que importa, a despeito da possibilidade onipresente de ressignificação dos objetos. Observemos a obra "Untitled", de Anish Kapoor, de 1983, exposta na Tate Gallery de Londres: 


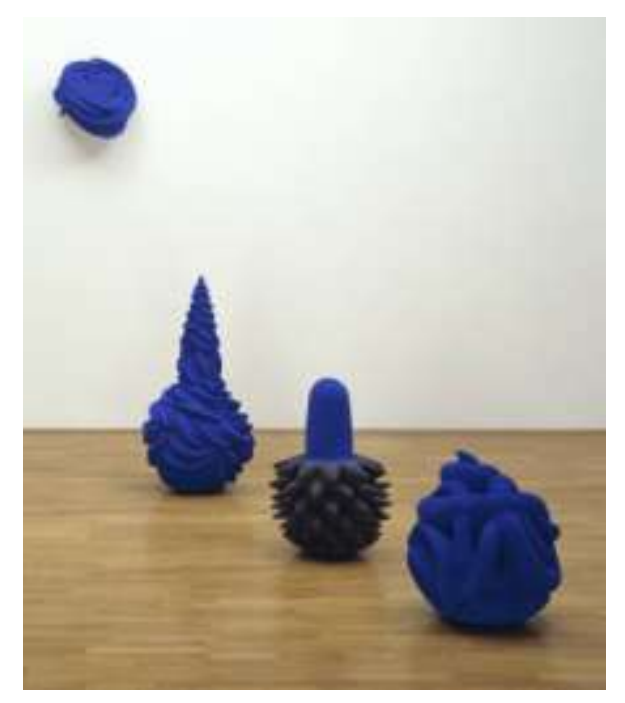

Figura 2: Obra "Untitled" (1983), de Anish Kapoor. Veja-se http://www.tate.org.uk/art/artworks/kapooruntitled-t13695

O site da Tate Gallery oferece uma descrição da obra. Essa descrição é como segue:

Esta escultura sem título compreende três formas livres afixadas no chão, dispostas numa linha diagonal, e uma quarta forma afixada acima delas na parede da galeria. Cada forma evoca um híbrido do natural com aquilo que é feito pelo homem, uma vez que são abstratas e estilizadas, mas curiosamente orgânicas. A relação entre as quatro formas separadas é determinada pela cor que compartilham - um azul intenso - e seu alinhamento espacial - um arranjo geométrico que parece ligar as formas. Este alinhamento encoraja o espectador a ler as formas colocadas no chão consecutivamente em termos de altura, da mais baixa, que está mais distante da parede, à mais alta, que está mais próxima dela. A mais baixa é redonda, mas de modo desigual, assemelhando-se a uma bola enrolada. A próxima justapõe uma base cravada de cones que se projetam para fora coloridos de cinza com um uma parte superior azul fálica e redonda. A mais alta unifica uma base redonda com um topo cônico; sua superfície ondulada evoca a textura de tecidos drapeados ou ondas. Na parede, a forma de bola levemente achatada da quarta forma assemelha-se a um broto de rosa estilizado ${ }^{3}$.

\footnotetext{
3 "This untitled sculpture comprises three ground-based, free-standing forms placed in a diagonal row, and a fourth form affixed above them on the gallery wall. Each shape evokes a hybrid of the natural and the man-made, as they are abstract and stylised yet curiously organic. The relationship between the four separate forms is determined by their shared colour - an intense blue - and their spatial alignment - a geometrical arrangement that seems to link the forms together. This arrangement encourages the spectator to read the ground-based forms consecutively in terms of height, from the lowest, which is furthest from the wall, to the tallest, which is closest to the wall. The lowest is round, but unevenly so, resembling a coiled ball. The next juxtaposes a spiked base of outward-thrusting cones coloured grey with a rounded, phallic upper part coloured blue. The tallest unites a round base with a conical top; its undulating surface evokes the textures of draped fabric or waves. On the wall,
} 
Nesta descrição, puramente denotativa, são expressas em palavras as qualidades dos objetos que compõem a escultura. São enunciadas suas cores, formas, disposição de suas partes. Em alguns momentos, ocorre a comparação de formas da escultura com formas conhecidas no mundo fenomênico consensual - o falo, a rosa. Mas não se está falando sobre falos e rosas, ou ao menos não no que eles representam e simbolizam; o que ocorre é mera alusão comparativa às suas qualidades perceptíveis visuais compartilhadas. Também se faz referência aos pigmentos que colorem as partes integrantes da obra, em uma referência à sua materialidade perceptível, tátil, sensual.

O autor teceu os seguintes comentários sobre esta obra:

"Agrada-me a ideia de que o objeto tem sua própria forma [Gestalt], sua própria resolução, mesmo que ele acumule outras camadas de sentido. Eu não estou falando de narrativa. Eles podem ter referências, mas não são objetos narrativos: eles não delineiam os processos de sua própria feitura. Ao mesmo tempo, há uma sugestão de ritual no traçado, a aspersão do pigmento, a delicadeza da superfície"

$\mathrm{O}$ artista nos está dizendo, em outras palavras, que sua obra apresenta formas não-representativas, as quais podem constituir-se em três graus: primeiramente, como talidade ou pura qualidade em si; em segundo lugar, como acontecimentos singulares, "apontando para o gesto que lhe[s] deu origem" e, em terceiro lugar, como lei ou invariância (SANTAELLA apud CUNHA, 2009, p. 77).

Deste modo, observa-se que essa obra, enquanto signo ou representamen, tem a si mesma como objeto ou referente, não podendo jamais ser entendida como símbolo. Ela discursa sobre como ela é, resumida a si mesma, sem referência a nada exterior a ela, sendo, assim, quase pura primeiridade. Digo quase pura porque ela também é uma conjunção de elementos materiais, existentes, que se impõem como percepto à percepção do intérprete, que se forçam e impõem sendo o que e como são independentemente das ideias e interpretações do fruidor, o que corresponde à secundidade. Ela é um existente (segundo) que incorpora qualidades (primeiras). Embora esta obra não se refira a nada que esteja fora dela mesma, ou seja, nada signifique e nada represente, ela discursa e declara o que é e como é para quem a vê - e,

the slightly flattened ball shape of the fourth form resembles a stylized rose bloom". Em <http://www.tate.org.uk/art/artworks/kapoor-untitled-t13695>, acesso em 04.12.2016.

4 "I like the idea that the object has its own Gestalt, its own resolvedness, even as it accumulates other layers of meaning. I'm not talking about narrative. They may have references, but they are not narrative objects: they don't delineate the process of their own making. At the same time, there is a suggestion of ritual in the layout, the sprinkling of pigment, the delicacy of the surface", em <http://www.tate.org.uk/art/artworks/kapoor-untitled-t13695>, acesso em 04.12.2016. Extraído de BAUME, Nicholas (ed.). Anish Kapoor: Past, Present, Future, exhibition catalogue, Institute of Contemporary Art, Boston 2008, p. 40. 
eventualmente, e se isso fosse permitido ou estimulado, a quem a tocasse, cheirasse, provasse. Esta obra, tomando-se por base a (não)-significação, é um signo de primeiridade. Ela não precisa significar nada para ser um signo, nem ser "semiotizada" por qualquer intérprete. Ela tem muito a dizer sobre si mesma desde que suficientemente contemplada. O que lhe faltam são traços de terceiridade no sentido de representação - mas ela traz, por exemplo, uma generalização do azul, uma aplicação dessa qualidade a quase todas as suas partes (invariância).

Ela diz a cada um de nós que a observamos: "Eu sou o que e como sou. Eu só me refiro a mim mesma, às minhas qualidades". Esta obra é, assim, profundamente ensimesmada. Ela é um fim em si mesma, com sua própria gramática, estando aquém da alo-referencialidade. Sem necessidade de ser semiotizada, ela não deixa de ser, em si, um signo. Deste modo, não é possível concordar com Marariños, ao menos a respeito de sua diferenciação entre signos e objetos semióticos. Um signo pode ser muito mais ou muito menos do que aquilo que ele afirma.

Uma pergunta que emerge, neste momento, é sobre o lugar ou não-lugar das formas não-representativas no livro ilustrado. Tradicionalmente (p. ex. Camargo, 1993; Ramos, 2011 e Linden, 2011), entende-se que as ilustrações desempenham funções no livro ilustrado, e essas funções geralmente apontam para a representação. Apesar disso, vemos com Kümmerling-Meibauer (2014) e os demais autores citados que imagens também podem narrar. Explorar as distintas funções de texto e imagem no livro ilustrado não faz parte do escopo deste trabalho, tratando-se, aqui, de apenas um exemplo. Por ora, vale lembrar que uma imagem que não narre e não represente, no livro ilustrado, poderia servir, se seguirmos o paradigma de entendimento da ilustração como tendo uma função, para, à guisa de exemplo, decorar o texto e o livro, em imagens que devam ser contempladas em suas qualidades, mas também para gerar estados emocionais no leitor, como o estranhamento e a inquietação. Observe-se a seguinte imagem de Grimm-Pacovská: 


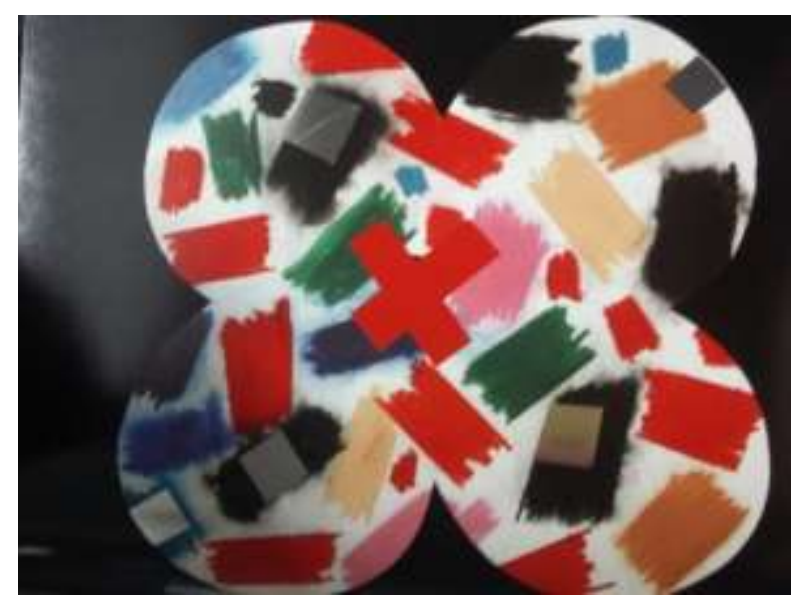

Figura 3: imagem de Grimm-Pacovská, 2007.

Esta imagem pode representar uma flor, mas, mesmo nesse caso, se impõe aos sentidos mais por suas qualidades de discurso visual que por seu eventual caráter representativo, que nem sequer é certo. A linguagem desta imagem é a das cores, dos rabiscos, da colagem. Ela é muito afeita à primeiridade porque é da ordem do possível e do qualitativo, e do que é o que é sem necessariamente referência a algo que lhe seja externo.

\section{Considerações finais}

Tendo observado tudo isso, e tendo visto com Santaella (1992) que, para Peirce, tudo é signo, fica aberta a questão a respeito do trecho em que ele diz (MS [R] 599:38) que um signo que apenas significa a si mesmo para si mesmo é apenas uma coisa (no sentido de um não-signo), e todos os trechos em que explica que um signo se refere a um objeto que é algo distinto dele, o que, com os comentaristas, vimos que só se aplica necessariamente ao símbolo. A impressão que se tem é a de se estar diante de uma contradição, e Peirce é associado, por seus detratores, a contradições. O que acredito, entretanto, é que o que tenha ocorrido nestes casos sejam simplificações como as que ele confessou a Lady Welby que produzia para fazer-se entender, para reduzir o grau de abstração de seus conceitos a título de torná-los mais compreensíveis e evitar seu rechaço. Também porque, nessas definições, Peirce priorizava e lançava luz à função primordial dos signos que é a de substituir e representar outras coisas, enquanto legisignos, símbolos e argumentos. Essa função, que ora chamo primordial, é muito mais objeto da semiótica do que a autorreferencialidade que, encerrada em si mesma, talvez instigue menos reflexões semióticas e diga menos sobre as capacidades extraordinárias dos signos tidos como genuínos ou mais desenvolvidos na vida social. Por isso, 
costuma-se afirmar que é preciso ler Peirce junto com seus comentadores, leitores muito mais experientes e sagazes de sua obra, e que desfazem esses equívocos que o contato com seus manuscritos, sobretudo se fora de ordem, pode causar.

\section{Referências}

BERGMAN, M.; PAAVOLA, S. (Eds.). The Commens Dictionary: Peirce's Terms in His Own Words; New Edition. Disponível em <http://www.commens.org/dictionary>. $s / d$.

CAMARGO, Luís. Ilustração do livro infantil. 2. ed. Belo Horizonte: Lê, 1993.

CUNHA, Maria Z. Na tessitura dos signos contemporâneos; novos olhares para a literatura infantil e juvenil. São Paulo: Paulinas, 2009.

GRIMM, Irmãos; PACOVKÁ, Kveta. Rotkäppchen. Bargteheide: Minedition/Michael Neubauer Edition, 2007. Página 11.

KÜMMERLING-MEIBAUER, Bettina. Introduction: picturebooks between representation and narration. In: narration. Nova York: Routledge, 2014. pp. 1-16.

MAGARIÑOS DE MORENTÍN, Juan. Conceito e método da semiótica. Trad. Darcília Simões. In: SIMÕES, Darcília (Org.) Mundos semióticos possíveis. Rio de Janeiro: Dialogarts, 2008. pp. 17-50.

NÖTH, Winfried. Handbuch der Semiotik. $2^{\mathrm{a}}$ ed. Stuttgart: J. B. Metzler, 2000.

RAMOS, Graça. A imagem nos livros infantis; caminhos para ler o texto visual. Belo Horizonte: Autêntica, 2011.

ROMANINI, Vinícius. Prolegômenos para uma teoria semiótica da auto-organização. In: BRESCIANI FILHO, E.; D’OTTAVIANO, I.M.L.; GONZÁLEZ, M.E.Q.; PELLEGRINI, A.M.; ANDRADE, R.S.C. de (Orgs.). Auto-organização; estudos interdisciplinares. Coleção CLE, v. 66, p. 367-405, 2014.

SANTAELLA, Lúcia. A assinatura das coisas; Peirce e a literatura. Rio de Janeiro: Imago, 1992.

SILVEIRA, Lauro F. Curso de semiótica geral. São Paulo: Quartier Latin, 2007.

LINDEN, Sophie van der. Para ler o livro ilustrado. São Paulo: Cosac Naify, 2011. 